DOI: https://doi.org/10.24127/ajpm.v10i2.3255

\title{
GENERALISASI DALAM PENALARAN KUANTITATIF SISWA MELALUI PEMECAHAN MASALAH PECAHAN
}

\author{
Syarifuddin $^{1^{*}}$ \\ 1*Pendidikan Matematika, STKIP Bima, Bima, Indonesia \\ *Corresponding author. Jalan Piere Tendean, Mpunda, 84111, Kota Bima, Indonesia. \\ E-mail: $\quad$ Syarifuddin.stkipbima@gmail.com ${ }^{1 *}$
}

Received 19 November 2020; Received in revised form 10 June 2021; Accepted 28 June 2021

\begin{abstract}
Abstrak
Tujuan penelitian ini adalah mendeskripsikan penalaran kuantitatif dalam proses generalisasi dan cara siswa dalam menghubungkan kuantitas. Jenis penelitian ini adalah penelitian kualitatif dengan pendekatan deskriptif eksploratif. Penelitian dilakukan pada siswa sekolah menengah (kelas 9) di daerah kabupaten Bima, Nusa Tenggara Barat. Penelitian ini melibatkan 35 orang siswa yang telah memperoleh materi pecahan sebagai subjek penelitian. Subjek yang deskripsikan pada hasil penelitian sebanyak 2 orang yang merepresentasikan dari subjek penelitian dan dilakukan proses seleksi dengan memberikan tes berupa soal pemecahan masalah pecahan sebanyak 2 nomor. Siswa yang terpilih berdasarkan representasi pemecahan masalah dan atas rekomendasi dari guru matematika terhadap siswa yang memiliki kemampuan menjelaskan secara lisan. Data penelitian dikumpulkan dari hasil representasi siswa dan hasil wawancara, kemudian dianalisis secara komprehensif untuk mengidentifikasi penalaran kuantitatif siswa. Hasil penelitian menunjukan: 1) penalaran kuantitatif siswa dapat menghasilkan generalisasi pola bilangan; 2) siswa menghubungkan kuantitas dengan menggunakan rasio ekuivalen; 3) siswa merepresentasikan masalah pecahan dapat menggunakan bentuk kesetaraan. Penelitian ini menemukan bahwa kuantitas atau unit dari pecahan matematika dapat membentuk suatu pola bilangan melalui proses perbandingan kuantitas.
\end{abstract}

Kata kunci: Pecahan; pemecahan masalah; penalaran kuantitatif.

\begin{abstract}
The research aimed to describe quantitative reasoning in student's generalization and manner of connecting the quantity. The recent study was a qualitative research with explorative descriptive approach. It was conducted to 9 grade secondary students at Bima, West Nusa Tenggara. There was 35 students who have learnt about fractions involved as the subject of the study. The representative subjects were 2 students who were selected through 2 numbers of problem solving test. The selected students were taken based on the test result and also teacher's recommendation dealing with students' ability in oral explanation. Data were collected from students' representation and interview results, thereafter were analyzed identifying students' quantitative reasoning comprehensively. The findings indicated, that: 1) students' quantitative reasoning generating number pattern generalization, 2) students connected the quantity utilizing equivalent ratio, 3) students represented fraction problem using equality form. The study found that the quantity or the unit of mathematics fraction could shape a number pattern through quantity comparison.
\end{abstract}

Keywords: Fraction; problem solving; quantitative reasoning.

This is an open access article under the Creative Commons Attribution 4.0 International License

\section{PENDAHULUAN}

Standar pembelajaran matematika (Depdiknas no. 22, 2006; NCTM, 2000) salah satunya adalah penalaran (reasoning). Dalam penerapannya, penalaran dipengaruhi oleh aktifitas kognitif dan kemudian terwujud dalam berbagai bentuk, salah satunya adalah 
penalaran kuantitatif. Penalaran kuantitatif merupakan proses kognitif untuk menggambarkan tindakan mental seorang siswa dalam memahami masalah matematika, mengonstruksi kuantitas dari masalah, menghubungkan, memanipulasi, dan menggunakan kuantitas dalam memecahkan masalah (Ellis, 2011; Moore, 2014; Weber et al., 2014).

Penalaran kuantitatif untuk mengembangkan penalaran aljabar siswa SMP dan sebagai akar dalam mengembangkan penalaran aljabar. Pengembangan ini tidak mudah dan tidak cepat untuk dilakukan, melainkan hanya siswa yang terampil dan memiliki berbagai pengalaman dalam waktu yang lama akan lebih baik pengetahuan aljabar karena membuat pengetahuan aritmetika dan aljabar lebih bermakna dan produktif. Terutama dalam kaitannya dengan pemahaman dan kemahiran siswa dalam menghasilkan generasilisasi dalam matematika.

Penelitian dalam penalaran kuantitatif yang berkaitan dengan pengembangan aljabar siswa sangat bergantung pada materi matematika. Diantaranya penelitian dalam memahami fungsi sinus pada trigonometri melalui segitiga siku-siku yang dihubungkan dengan jari-jari pada lingkaran (Moore, 2014). Kemudian penelitian tentang pemahaman pra variabel siswa sekolah dasar dengan menggunakan kuantitas dalam pecahan (Hackenberg \& Lee, 2015).

Memahami perkembangan generalisasi aljabar siswa dalam penelitian ini adalah mengacu pada penelitian Hackenberg \& Lee (2015), dimana penelitian ini hanya melihat perkembangan penalaran siswa pra pemahaman tentang variabel. Hasil penelitiannya menunjukan bahwa ketika siswa disuruh menuliskan $5 / 7$ dari unit (pecahan) yang mereka gambar, maka siswa mudah saja menuliskan $5 / 7$, tetapi siswa kesulitan menuliskan bentuk 9/7. Pengembangan penelitian tersebut (Syarifuddin et al., 2020) tentang penalaran kuantitatif siswa dalam proses pemecahan masalah pecahan dengan pendekatan variabel dan non-variabel, menemukan bahwa siswa menghubungkan kuantitas atau unit secara langsung.

Penelitian tersebut terbatas pada penyelidikan perkembangan pravariabel siswa dan penggunaan varibel dalam menghubungkan kuantitas. Sehingga penelitian ini menyelidiki perkembangan penalaran kuantitatif siswa pada masalah pecahan yang berkaitan dengan generalisasi yang dilakukan oleh siswa dalam pemecahan masalah pecahan. Beberapa penelitian lain belum mengkaji hal yang sama dengan penelitian ini.

Penalaran kuantitatif memiliki fokus penting pada pemecahan masalah. Kemampuan yang dimiliki dalam pemecahan masalah tersebut antara lain, membaca dan memahami informasi yang diberikan dalam berbagai format; menafsirkan informasi kuantitatif dan menarik kesimpulan; memecahkan masalah menggunakan aritmatika, aljabar, geometri, atau metode statistik; memperkirakan jawaban dan memeriksa kewajaran; mengkomunikasikan informasi kuantitatif; dan mengakui keterbatasan metode matematika atau statistik (Syarifuddin et al., 2020).

Masih banyak siswa SMP yang masih kesulitan dalam menyelesaikan masalah pecahan (Murniasih et al., 2020; Syarifuddin et al., 2019b). Sebagian siswa mahir dalam memecahkan masalah yang bersifat abstrak, sementara siswa yang lain lebih suka memecahkan masalah kontekstual (Sa'dijah et al., 2019; Sa'diyah et al., 2019). 
DOI: https://doi.org/10.24127/ajpm.v10i2.3255

Representasi visual dapat membantu siswa dalam memaknai masalah yang abstrak, sehingga siswa dapat memecahkan masalah pecahan (Abdullah et al., 2017; Atmarita \& Syarifuddin, 2021; Fadhilah et al., 2019). Representasi visual pada pecahan dapat memberi pengaruh yang baik dalam menentukan representasi simbolik (Atagi et al., 2016), akan tetapi representasi simbolik dan numerik ke representasi visual tidak dapat dilakukan dengan baik (Lewis, 2016), dan siswa yang kurang mampu dalam matematika akan kurang efektif dalam belajar pecahan, tetapi dapat diperbaiki melalui rekonseptualisasi remedial (Lewis, 2017; Palpialy \& Nurlaelah, 2015).

\section{METODE PENELITIAN}

Penelitian ini merupakan penelitian kualitatif dengan melakukan analisis data berdasarkan fakta-fakta yang ditemukan di lapangan. Kemudian dilanjutkan dengan mengkonstruksikan menjadi sebuah hipotesis, teori, atau interpretasi. Pendekatan penelitian yang digunakan adalah pendekatan deskriptif eksploratif.
Penelitian dilakukan pada siswa SMP kelas 9 di salah satu SMP Negeri di kabupaten Bima, NTB. Pemilihan subjek dilakukan dengan memberikan soal kepada 35 siswa. Siswa yang terpilih berdasarkan representasi pemecahan masalah, kemudian dari hasil tes tersebut dipilih subjek yang merepresentasikan penalaran kuantitatif. Selanjutnya dikonsultasikan dengan guru matematika dan meminta rekomendasi dari guru tersebut untuk menentukan siswa yang memiliki kemampuan komunikasi dan dapat menjelaskan secara lisan. Adapun siswa yang direkomendasi oleh guru sebanyak 2. Penyebutan subjek dalam hasil peneliti-an, yaitu Subjek 1 (S1) dan Subjek 2 (S2).

\section{Pengumpulan dan Analisis Data}

Proses penelitiannya yaitu dengan memberikan tes berupa soal pemecahan masalah pecahan untuk mendeskripsikan penalaran kuantitatif siswa. Soal yang digunakan sebanyak 2 nomor seperti terlihat pada Gambar 1. Soal pertama untuk mendeskripsikan penalaran kuantitatif, kemudian soal kedua adalah untuk mendeskripsikan cara siswa menghubungkan kuantitas.

1. Ali, Budi, dan Cinta akan mengisi ember mereka masing-masing dengan buah apel. Apel diambil dari ember besar yang berisi banyak apel. Ali mengambil 2 apel, Budi mengambil 3 apel dan Cinta mengambil 4 apel setiap kali mengisi ember masing-masing. Pengambilan dilakukan berkali-kali dengan jumlah yang tetap sama. Catatlah pertambahan jumlah apel dalam ember masing-masing anak pada setiap pengambilan yang dilakukan.

2. Dari pengambilan apel di atas, misalnya ember si Ali berisi apel sebanyak 20 buah. Ali memberikan apel nya sebanyak 5 buah kepada Dedi.

a. Berapa bagiankan apel Ali yang diberikan ke Dedi?

b. Berapa bagiankan sisa apel Ali?

Gambar 1. Soal pemecahan masalah pecahan matematika

Setelah siswa mengerjakan soal, kemudian dilakukan wawancara untuk mengetahui dan mengintepretasikan proses penalaran kuantitatif dalam menguraikan jawabannya. Subjek yang di wawancara dipilih dengan melihat hasil kerja (lembar jawaban).

Analisis data dengan melihat hasil representasi siswa terhadap pemecahan masalah pecahan yang mengarah pada penalaran kuantitatif siswa dengan 
mengacu pada indokator (Syarifuddin et al., 2019a), seperti pada Tabel 1. Kemudian menganalisis hasil wawancara dengan cara melihat dan menganalisis kembali transkrip wawancara yang telah dicatat selama wawancara berlangsung. Selanjutnya adalah analisis komprehensif dari hasil representasi siswa dalam bentuk jawaban tertulis dengan hasil wawancara siswa untuk mengidentifikasi penalaran siswa dalam menghubungkan kuantitas.

Tabel 1. Indikator proses penalaran kuantitatif dalam pemecahan masalah

\begin{tabular}{|c|c|}
\hline Penalaran kuantitatif & Indikator \\
\hline $\begin{array}{l}\text { Membaca dan memahami } \\
\text { informasi dalam berbagai bentuk. }\end{array}$ & $\begin{array}{l}\text { Mengidentifikasi dan menuliskan kuantitas } \\
\text { yang terlibat dalam masalah atau soal. }\end{array}$ \\
\hline $\begin{array}{l}\text { Menafsirkan informasi kuantitatif } \\
\text { dan menarik kesimpulan yang } \\
\text { tepat. }\end{array}$ & $\begin{array}{l}\text { Menuliskan kuantitas dalam simbol-simbol } \\
\text { yang sudah dikenal. }\end{array}$ \\
\hline $\begin{array}{l}\text { Memecahkan masalah dengan } \\
\text { menggunakan metode aritmatika, } \\
\text { aljabar, atau geometrik. }\end{array}$ & $\begin{array}{l}\text { Menentukan dan menuliskan } \\
\text { penyelesaian masalah, baik dengan } \\
\text { aritmatika, aljabar, atau menggambar. }\end{array}$ \\
\hline $\begin{array}{l}\text { Memperkirakan jawaban dan } \\
\text { memeriksa kewajaran }\end{array}$ & $\begin{array}{l}\text { Memeriksa dan meyakini kembali jawaban } \\
\text { yang telah diuraikan. }\end{array}$ \\
\hline $\begin{array}{l}\text { Mengkomunikasikan informasi } \\
\text { kuantitatif }\end{array}$ & $\begin{array}{l}\text { Menjelaskan bentuk hubungan kunatitas yang } \\
\text { terbentuk, baik secara analitik atau secara } \\
\text { intuisi. }\end{array}$ \\
\hline \multirow{2}{*}{$\begin{array}{l}\text { Mengenali keterbatasan metode } \\
\text { matematika yang digunakan. }\end{array}$} & Memahami kembali apa yang telah dilakukan. \\
\hline & $\begin{array}{l}\text { Mengakui dan memperbaiki kembali bila } \\
\text { terjadi kesalahan dalam proses penalaran. }\end{array}$ \\
\hline
\end{tabular}

\section{HASIL DAN PEMBAHASAN}

Pada hasil penelitian ini akan diuraikan hasil representasi dan wawancara dari 2 subjek yang terdiri dari S1 dan S2. Adapun hasil yang diperoleh dalam penelitian ini sebagai berikut:

\section{Hasil Representasi dan Wawancara Terhadap S1}

Hasil representasi dan wawancara $S 1$ untuk soal nomor 1

Subjek S1 merepresentasikan jawabannya terhadap soal nomor 1 seperti terlihat pada Gambar 2.

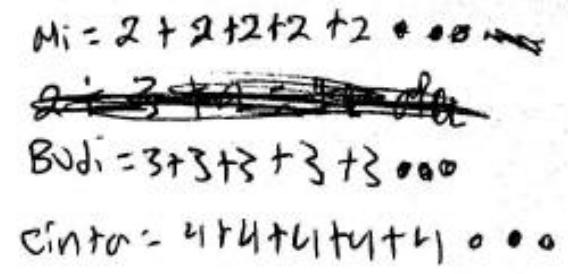

Gambar 2. Representasi S1 terhadap soal nomor 1

Representasi S1 pada Gambar 2 tersebut di atas diperkuat oleh hasil wawancara dengan $\mathrm{S} 1$ berikut ini.

Peneliti : Coba saudara jelaskan, bagaimana maksud yang saudara tuliskan ini? (Sambil menunjuk jawaban S1 terhadap nomor 1a).

S1 : Ali mengambil 2 apel terus menerus sasmpai apel dalam ember habis, Budi mengambil 
DOI: https://doi.org/10.24127/ajpm.v10i2.3255

\begin{abstract}
3 apel dan seterusnya, begitupun Cinta mengambil 4 apel dan seterusnya. Ali mengambil apel sebanyak 2 ditambah lagi dua ditambah lagi dua ditambah lagi dua dan seterusnya. Budi mengambil apel sebanyak 3 buah yaitu tiga ditambah tiga ditambah tiga ditambah tiga dan seterusnya. Cinta mengambil 4 buah apel, kalau dijumlahkan menjadi empat ditambah empat ditambah empat ditambah empat ditambah empat dan seterusnya.
\end{abstract}

Representasi sebagaimana ditunjukan pada Gambar 2 bahwa S1 mulai memecahkan masalah pecahan dengan metode aljabar. S1 menunjukan proses generalisasi pola bilangan penjumlahan dengan menuliskan tiga titik yang melambangkan kalimat seterusnya. Pada tahap mengkomunikasikan informasi kuantitatif, S1 menguraikannya pada proses wawancara dengan mengatakan kalimat "dan seterusnya" yang menunjukan proses generalisasi yang terjadi dari penalaran kuantitatif pada masalah pecahan tersebut, sebagaimana terlihat pada kutipan wawancara tersebut di atas.

Hasil representasi dan wawancara $S 1$ untuk soal nomor $2 a$

Subjek S1 kemudian merepresentasikan jawabannya terhadap soal nomor $2 \mathrm{a}$ seperti terlihat pada Gambar 3.

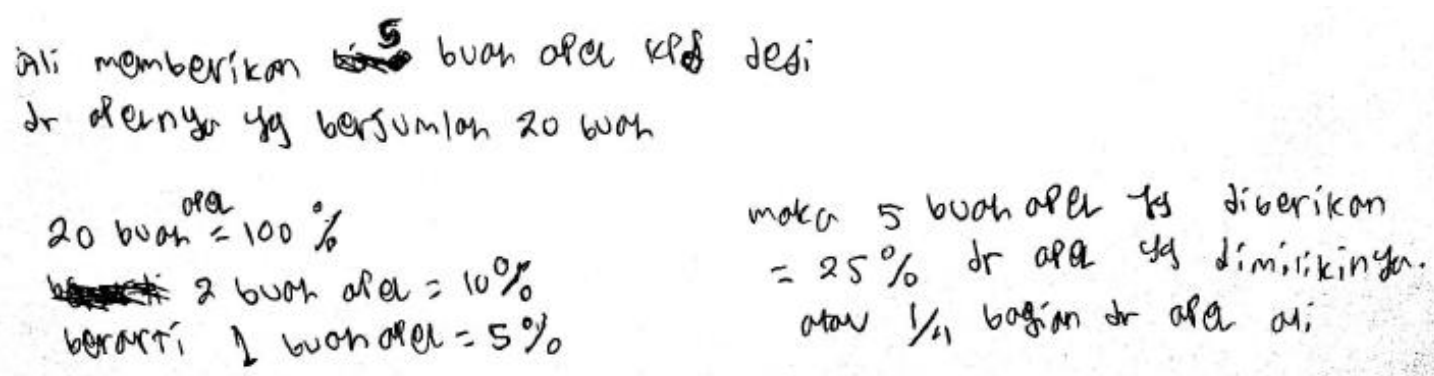

Gambar 3. Representasi S1 terhadap soal nomor 2a

Representasi S1 pada Gambar 3 tersebut di atas diperkuat oleh hasil wawancara dengan S1 berikut ini.

Peneliti : Coba saudara jelaskan, bagaimana maksud yang saudara tuliskan ini? (Sambil menunjuk jawaban S1 terhadap nomor 2a)

S1 : Ali memberikan 5 buah apel kepada Dedi dari apelnya yang berjumlah 20. Sama dengan 20 buah apel Ali sama dengan 100 porsen. 2 buah apel sama dengan 10 porsen, berarti 1 buah apel sama dengan 5 porsen, maka 5 buah apel yang diberikan sama dengan 25 porsen dari apel yang dimiliki nya atau seperempat bagian dari apel Ali.

Hasil representasi dan wawancara $S 1$ untuk soal nomor $2 b$

Subjek

S1 kemudian merepresentasikan jawabannya terhadap soal nomor $2 b$ seperti terlihat pada Gambar 4. 
DOI: https://doi.org/10.24127/ajpm.v10i2.3255

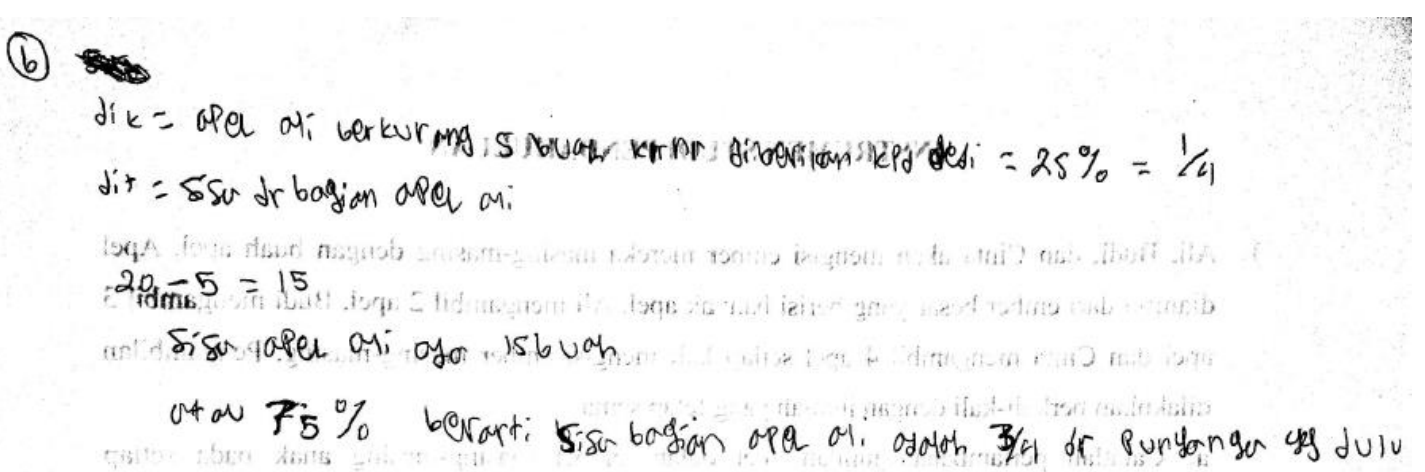

Gambar 4. Representasi S1 terhadap soal nomor $2 b$

Representasi S1 pada Gambar 4 tersebut di atas diperkuat oleh hasil wawancara dengan S1 berikut ini.

Peneliti : Coba saudara jelaskan, bagaimana maksud yang saudara tuliskan ini? (Sambil menunjuk jawaban S1 terhadap nomor $2 \mathrm{~b}$ ).

S1 : Diketahui apel Ali berkurang 5 buah karena diberikan kepada Dedi, sama dengan 25 porsen sama dengan seperempat. Diketahui, ditanya, sisa dari bagian apel Ali, jawaban nya 20 kurang 15 sama dengan 15. Sisa apel Ali adalah 15 buah atau 75 porsen berarti sisa bagian apel Ali adalah 3 per 4 dari punyanya yang dulu.

Berdasarkan hasil representasi dan wawancara yang dilakukan dengan S1 terhadap hasil kerjanya pada soal nomor 1, dapat memaknai kedalam penjumlahan berulang dan bisa melakukan generalisasi dengan ditunjukan dengan kalimat seterusnya. Kemudian dapat mengidentifikasi dan mengelompokan hasil pengambilan kedalam kategori yang sama dan menggeneralisasi untuk pengambilan selanjutnya dan kemudian menyimpulkan bagian terkecil yang sama dari beberapa pengambilan.
Wawancara dengan S1 pada soal nomor 2 menunjukan, S1 dapat merepresentasikan kuantitas secara keseluruhan kedalam $100 \%$. Kemudian menyederhanakan dari 20 buah ke 2 buah menjadi $10 \%$, dan sampai pada unit paling kecil yaitu 1 buah yang dianggap sebagai 5\%. Dari pernyederhaan tersebut dapat dijadikan sebagai dasar menentukan bagian yang diberikan kepada Budi. Sehingga S1 dapat menyimpulkan 5 bagian dari 20 yaitu $25 \%$. Proses menghubungkan kuantitas yang dilakukan oleh S1 adalah dengan membuat rasio ekuivalen dari kuantitas yaitu dengan cara memandang secara keseluruhan, kemudian mempartisi sampai pada unit terkecil dan selanjutnya menghubungkan kembali dengan unit untuk menemukan suatu solusi.

S1 tersebut dapat menunjukan bentuk lain dari persen yaitu dengan mempartisi unit yang dari 20 dianggap satu kesatuan dan menyebutkannya kedalam bentuk pecahan. Ini ditunjukan dengan bentuk $25 \%$ yang disebutnya dengan $1 / 4$ bagian dan $75 \%$ disebutkan dengan $3 / 4$ bagian. Proses pembentukan pecahan tersebut dengan menggunakan sifat kesetaraan.

Cara siswa menghubungkan kuantitas dan pembentukan pecahan tersebut sesuai dengan penelitian terdahulu (Empson et al., 2011; Syarifuddin, 2019; Syarifuddin et al., 
DOI: https://doi.org/10.24127/ajpm.v10i2.3255

2020), dimana siswa menciptakan rasio dalam menghubungkan dua kuantitas untuk membangun kuantitas baru. Kemudian siswa menggunakan sifat kesetaraan sebagai cara menghubungkan kuantitas dengan menggunakan distributif properti, berpikir relasional. Disamping itu, siswa bisa berpikir secara reversible dengan menyederhanakan bentuk menjadi bentuan satuan $(1$ apel $=5 \%$, kemudian dikalikan lagi dengan dengan 5 apel sehingga mengahasilkan $25 \%$.

\section{Hasil Representasi dan Wawancara Terhadap S2}

Hasil representasi dan wawancara $S 2$ untuk soal nomor 1

Subjek S2 kemudian merepresentasikan jawabannya terhadap soal nomor 1 seperti terlihat pada Gambar 5.

$$
\begin{aligned}
& \text { Ali mengambil apel } 2 \text { buah setiap mengioi embernya } \\
& \text { (a) Budi mengambil apel s buah retiap mengini embernya } \\
& \text { cinta mengambil apel } 4 \text { buah retiap mengisi embernya } \\
& \text { jorth apet retiap lo kati } \\
& \text { Maka setiap Ali menglsi embernya } 10 \text { kali berjumlh } \\
& 20 \text { apel, Budi mengisi embernya } 10 \text { bali berimih } \\
& 30 \text { apel, sdglean cinta mengiri embernya } 10 \text { kalli } \\
& \text { berjimin to apel. }
\end{aligned}
$$

Gambar 5. Representasi S2 terhadap soal nomor 1

Representasi S2 pada Gambar 5 tersebut di atas diperkuat oleh hasil wawancara dengan S2 berikut ini.

Peneliti : Coba saudara jelaskan, bagaimana maksud yang saudara tuliskan ini? (Sambil menunjuk jawaban S2 terhadap nomor 1).

S2 : Ali mengambil apel 2 buah setiap mengisi ember nya, Budi mengambil 3 apel setiap mengisi ember nya, Cinta mengambil 4 apel setiap mebisi embernya, maka setiap Ali mengisi embernya 10 kali berjumlah 20 apel, Budi mengisi embernya 10 kali berjumlah 30 apel, sedangkan Cinta mengisi embernya 10 kali berjumlah 40 apel.
Hasil kerja dan wawancara untuk soal nomor $2 a$ dan $2 b$

Subjek S2 kemudian merepresentasikan jawabannya terhadap soal nomor 2 seperti terlihat pada Gambar 6.

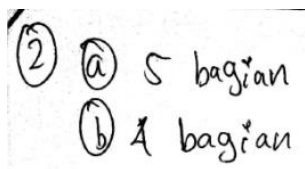

Gambar 6. Hasil Kerja S2 nomor 2

Representasi S2 diperkuat oleh hasil wawancara dengan $\mathrm{S} 2$ berikut ini.

Peneliti : Coba saudara jelaskan, bagaimana maksud yang saudara tuliskan ini? (Sambil menunjuk jawaban S2 terhadap nomor 1$)$.

$\mathrm{S} 2$ : 5 bagian (tidak bisa menjelaskan).

Peneliti : Trus empat bagian ini apa?

S2 : Sisanya adalah 4 bagian. 
Dari hasil wawancara yang dilakukan dengan S2, terlihat penalaran yang dibangun oleh S2 adalah membatasi berpikirnya hanya sampai pada titik tertentu saja yaitu pengambilan dilakukan sampai 10 kali. Sehingga untuk proses selanjutnya S2 dipengaruhi oleh batasan yang telah ditentukan. Tetapi dalam hal ini S2 mampu mandapatkan hasil untuk pengambilan yang ke- $n$ dengan cara langsung mengalikannya. Hal ini sesuai dengan hasil penelitian bahwa koneksi matematis (menghubungkan kuantitas) dapat melibatkan konjektur untuk meyakini kebenaran pola maupun rumus yang dihasilkan dalam menggeneralisasi (Sutarto et al., 2018; Zulaini et al., 2019). Peneliti lain telah melihat pada situasi kuantitatif sebagai dasar bagi siswa untuk membangun hubungan kuantitatif yang melibatkan pecahan atau desimal, membuat generalisasi, dan menggunakan notasi aljabar untuk melambangkan generalisasi tersebut (Empson et al., 2011). Perancangan tugas memberikan fokus pemecahan masalah yang dirancang untuk melibatkan siswa dalam proses aljabar yaitu generalisasi, representasi, pembenaran (justification), dan penalaran dengan hubungan matematika (Blanton et al., 2015).

$$
\text { Menghubungkan }
$$

kuantitas

pecahan yang dilakukan oleh S1 dan S2 dilakukan dengan mengkombinasikan operasi penjumlahan, perkalian, dan pembagian. Proses menghubungkan kuantitas tersebut melibatkan penalaran kuantitatif dengan operasi kuantitatif yang berbeda yaitu kombinasi kuantitas secara perkalian, kombinasi kuantitas secara penjumlahan, dan kombinasi perkalian dan penjumlahan secara bersamaan (Syarifuddin et al., 2020). Dalam merepresentasikan penalaran kuantitatif tersebut, siswa mewujudkan dalam bentuk simbolik dan verbal. Representasi simbolik terjadi secara eksternal, sedangkan representasi verbal dapat terjadi secara eksternal dan internal. Representasi dapat terjadi secara eksternal dan internal melalui proses kognitif yang berbentuk analogi dan perspektif. Hal ini didukung oleh dari hasil penelitian yang menguraikan bahwa siswa secara eksplisit atau implisit menggunakan sifat dasar dari operasi aritmatika dan kesetaraan sebagai cara menghubungkan kuantitas dengan menggunakan distributif properti, berpikir relasional (Empson et al., 2011; Syarifuddin, 2018).

\section{KESIMPULAN DAN SARAN}

Berdasarkan hasil penelitian, wawancara, dan pembahasan dalam penelitian ini menunjukkan bahwa: 1) penalaran kuantitatif siswa menghasilkan generalisasi pola bilangan; 2) siswa menghubungkan kuantitas dengan menggunakan rasio ekuivalen; 3) dalam merepresentasikan masalah pecahan, siswa dapat menggunakan bentuk kesetaraan. Dari ketiga hasil penelitian tersebut memberikan temuan penelitian bahwa kuantitas atau unit dari pecahan matematika dapat membentuk suatu pola bilangan melalui proses perbandingan kuantitas.

Dari hasil dan temuan penelitian tersebut menunjukan siswa dapat melakukan generalisasi dengan menentukan pola bilangan suku ke- $n$, maka perlu dilakukan penelitian lebih lanjut untuk mengkaji penalaran kuantatif siswa dalam membangun generalisasi pola bilangan tersebut.

\section{DAFTAR PUSTAKA}

Abdullah, A. H., Abidin, N. L. Z., \& Mokhtar, M. (2017). Using Thinking Blocks to Encourage the 
DOI: https://doi.org/10.24127/ajpm.v10i2.3255

Use of Higher Order Thinking Skills among Students When Solving Problems on Fractions. International Journal of Educational and Pedagogical Sciences.

https://doi.org/scholar.waset.org/1 999.10/10006278

Atagi, N., DeWolf, M., Stigler, J. W., \& Johnson, S. P. (2016). The role of visual representations in college students' understanding of mathematical notation. Journal of Experimental Psychology: Applied. https://doi.org/10.1037/xap00000 90

Atmarita, A., \& Syarifuddin, S. (2021). Visual Processing Assessment on Children: A Pilot Study. Jurnal Pendidikan Dan Pembelajaran Indonesia (JPPI), 1(1), 1-9. https://doi.org/10.53299/jppi.v1i1. 18

Blanton, M., Stephens, A., Knuth, E., Gardiner, A. M., Isler, I., \& Kim, J. S. (2015). The development of children's algebrai thinking: The impact of a comprehensive early algebra intervention in third grade. Journal for Research in Mathematics Education, 4(1), 3987.

https://doi.org/10.5951/jresemathe duc.46.1.0039

Depdiknas no. 22. (2006). Standar Isi untuk Satuan Pendidikan Dasar dan Menengah. Peraturan Menteri Pendidikan Nasional Republik Indonesia, Nomor 22, Tahun 2006.

Ellis, A. B. (2011). Algebra in the Middle School: Developing Functional Relationships Through Quantitative Reasoning. In Cai Jinfa \& E. and Knuth (Ed.), Early Algebraization: A Global
Dialogue from Multiple

Perspectives (pp. 215-238).

Berlin, Heidelberg: Springer Berlin Heidelberg. https://doi.org/10.1007/978-3642-17735-4_13

Empson, S. B., Levi, L., \& Carpenter, T. P. (2011). The Algebraic Nature of Fractions: Developing Relational Thinking in Elementary School. In J. Cai \& E. Knuth (Eds.), Early Algebraization: A Global Dialogue from Multiple Perspectives (pp. 409-428). Springer Berlin Heidelberg. https://doi.org/10.1007/978-3642-17735-4_22

Fadhilah, N., Budiarto, M. T., \& Rahaju, E. B. (2019). Mathematical Representation of Middle School Students in Solving Fractional Problems Based on Sex Difference. Journal of Physics: Conference Series. https://doi.org/10.1088/17426596/1417/1/012048

Hackenberg, A. J., \& Lee, M. Y. (2015). Relationships Between Students' Fractional Knowledge and Equation Writing. Journal for Research in Mathematics Education, 46(2), 196-243.

Lewis, K. E. (2016). Beyond Error Patterns: A Sociocultural View of Fraction Comparison Errors in Students with Mathematical Learning Disabilities. Learning Disability Quarterly. https://doi.org/10.1177/07319487 16658063

Lewis, K. E. (2017). Designing a Bridging Discourse: ReMediation of a Mathematical Learning Disability. Journal of the Learning Sciences. https://doi.org/10.1080/10508406.20 16.1256810 
Moore, K. C. (2014). Quantitative reasoning and the sine function: The case of Zac. Journal for Research in Mathematics Education, 45(1), 102-138. https://doi.org/10.5951/jresemathe duc.45.1.0102

Murniasih, T. R., Sadijah, C., Muksar, M., Susiswo, S., \& Suwanti, V. (2020). Kesalahan Representasi Pecahan pada Garis Bilangan. AKSIOMA: Jurnal Program Studi Pendidikan Matematika, 9(2), 316-325.

NCTM. (2000). Principles and Standards for School Mathematics. The National Council of Teachers of Mathematics.

Palpialy, J. J., \& Nurlaelah, E. (2015). Pengembangan Desain Didaktis Materi Pecahan pada Sekolah Menengah Pertama (SMP). Jurnal Matematika Integratif, 11(2), 127-136.

https://doi.org/https://doi.org/10.2 4198/jmi.v11.n2.9425.127-136

Sa'dijah, C., Handayani, U. F., Sisworo, Sudirman, Susiswo, Cahyowati, E. T. D., \& Sa'Diyah, M. (2019). The Profile of Junior High School Students' Mathematical Creative Thinking Skills in Solving Problem through Contextual Teaching. Journal of Physics: Conference Series. https://doi.org/10.1088/17426596/1397/1/012081

Sa'diyah, M., Sa'dijah, C., Sisworo, \& Handayani, U. F. (2019). How Students Build Their Mathematical Dispositions towards Solving Contextual and Abstract Mathematics Problems. Journal of Physics: Conference Series. https://doi.org/10.1088/17426596/1397/1/012090
Sutarto, S., Nusantara, T., Subanji, S., Dwi Hastuti, I., \& Dafik, D. (2018). Global conjecturing process in pattern generalization problem. Journal of Physics: Conference Series. https://doi.org/10.1088/17426596/1008/1/012060

Syarifuddin, Nusantara, T., Qohar, A., \& Muksar, M. (2019a). Quantitative reasoning process in mathematics problem solving: A case on covariation problems reviewed from Apos theory. Universal Journal of Educational Research, 7(10), 2133-2142. https://doi.org/10.13189/ujer.2019 .071011

Syarifuddin, Nusantara, T., Qohar, A., \& Muksar, M. (2019b). The Identification Difficulty of Quantitative Reasoning Process toward the Calculus Students' Covariation Problem. Journal of Physics: Conference Series, 1254(1). https://doi.org/10.1088/17426596/1254/1/012075

Syarifuddin, S. (2018). Representasi Penalaran Kuantitatif Siswa dalam Pemecahan Masalah Matematika. Dalam Prosiding Seminar Nasional Lembaga Penelitian Dan Pendidikan (LPP) Mandala, (pp. 434-438).

Syarifuddin, S., Nusantara, T., Qohar, A., \& Muksar, M. (2020). Students' Thinking Processes Connecting Quantities in Solving Covariation Mathematical Problems in High School Students of Indonesia. Participatory Educational Research, 7(3), 5978. https://doi.org/10.17275/per.20.35.7. 3 
DOI: https://doi.org/10.24127/ajpm.v10i2.3255

Syarifuddin, S. (2019). Identifikasi Kesulitan Representasi Matematis Siswa SMP pada Pemecahan Masalah Pecahan. Supermat (Jurnal Pendidikan Matematika), 3(1), 34-42. https://doi.org/10.33627/sm.v3i1. 174

Syarifuddin, Syarifuddin, Nugroho, P. B., Mutmainah, M., Hadi, A. M., \& Sriaryaningsyih, S. (2020). The connecting quantities process to solve fraction mathematical problems of middle school students. Humanities and Social Sciences Reviews, 8(5), 121-131. https://doi.org/10.18510/hssr.2020 .8512

Weber, E., Ellis, A., Kulow, T., \& Ozgur, Z. (2014). Six Principles for Quantitative Reasoning and Modeling. The Mathematics Teacher, 108(1), 24-30. https://doi.org/10.5951/mathteach er.108.1.0024

Zulaini, Z., Sutarto, S., \& Juliangkary, E. (2019). Analisis Koneksi Matematis Siswa pada Proses Conjecturing dalam Menggeneralisasi pada Pola. JPIn: Jurnal Pendidik Indonesia, 2(2), 68-76. https://doi.org/10.47165/jpin.v2i2. 79 